\title{
The effect of aluminum coating to corrugated packaging on quality characteristics of paprika during storage
}

\author{
Ah-Na Kim ${ }^{1}$, Myeong-Hwa $\mathrm{Ha}^{2}$, Kyo-Yeon Lee ${ }^{1}$, M. Shafiur Rahman ${ }^{1}$, \\ Nam-Sub Kim ${ }^{3}$, Sung-Gil Choi ${ }^{1,4 *}$ \\ ${ }^{1}$ Division of Applied Life Science, Gyeongsang National University, Jinju 52828, Korea \\ ${ }^{2}$ Division of the Support and Planning, Gyeongsangnam-do Agricultural Research and Extension Services, Jinju 52733, Korea \\ ${ }^{3}$ Design Pack, Jinju 52799, Korea \\ ${ }^{4}$ Division of Food Science and Technology (Institute of Agriculture and Life Scieces), \\ Gyeongsang National University, Jinju 52828, Korea
}

\section{골판지 포장재에 알루미늄 코팅이 파프리카의 저장 중 품질특성에 미치는 영향}

\author{
김아나 ${ }^{1} \cdot$ 하명화 $^{2} \cdot$ 이교연 ${ }^{1} \cdot$ 샤피어라만 $^{1} \cdot$ 김남섭 $^{3} \cdot$ 최성길 ${ }^{1,4 *}$ \\ ${ }^{1}$ 경상대학교 응용생명과학부 응용생명과학전공, ${ }^{2}$ 경상남도농업기술원, ${ }^{3}$ 디자인팩, \\ ${ }^{4}$ 경상대학교 농화학식품공학과( 농업생명과학연구원)
}

\begin{abstract}
The objective of this study was to investigate the effect of comugated packaging coated with aluminum (AI) on quality characteristics of red paprika during storage at $25^{\circ} \mathrm{C}$. Characteristics such as weight loss, hardness, total phenolic content, antioxidant activities, polygalacturonic acid (PG) activity, and oxidative enzyme activities (polyphenol oxidase and peroxidase activities) of paprikas, packed in comugated packaging with or without Al-coating were compared as a function of storage time. Al coating inside of comugated box was found to inhibit PG activity, resulting in prevention of weight loss and maintenance of hardness of paprika during storage, compared to the control sample. This may be due to Al coating treatment that enhance moisture-proof property and hinder gas transmission of comugated packaging. Furthermore, paprika in Al-coated-comugated packaging was lower in oxidative enzyme activities than the control, which caused higher total phenolic content and antioxidant activities during storage. As a results, the $\mathrm{Al}$ coated-comugated packaging can be used as a functional packaging material to extend the shelf-life and improve the storage quality of paprika by preventing their respiration and transpiration.
\end{abstract}

Key words : comugated packaging, aluminum, paprika, storage, quality characteristics

\section{서 론}

파프리카(Capsicum annuum L.)는 대형과의 단고추로서 매운맛이 약하고 단맛이 강한 특징이 있으며, sweet pepper, bell pepper, pimento, paprika 등으로 부르고 있다 $(1,2)$. 파프

*Corresponding author. E-mail : sgchoi@gnu.ac.kr Phone : 82-10-7143-3100, Fax : 82-55-772-1909

Received 13 October 2017; Revised 24 November 2017; Accepted 27 November 2017.

Copyright (c) The Korean Society of Food Preservation. All rights reserved.
리카는 주요 카로티노이드계 색소성분 구성에 따라 적색, 주황색, 노란색, 녹색 등 다양한 색을 띄게 된다. 이러한 카로티노이드의 우수한 항산화 작용이 밝혀지면서 이를 섭취하였을 때 면역 증진, 눈 건강, 암, 심혈관 질환, 노인성 황변증 및 동맥경화 예방 등 다양한 건강증진 효과를 입증 하는 여러 연구가 보고되고 있다(3-6). 또한 파프리카는 비 타민 $\mathrm{A}, \mathrm{B}_{1}, \mathrm{C}, \mathrm{E}$ 와 카로티노이드, 페놀화합물와 같은 파이 토케미컬의 우수한 급원이며, 이것의 기호적 특성으로 인 해 샐러드나 구색 채소로 주로 이용되고 있다(7). 따라서 높은 품질 및 기호특성을 가진 파프리카는 지속적으로 국내 재배 및 소비와 수출이 증가하고 있으며, 우리나라의 대표 
적인 수출작물로 알려져 있다(8). 하지만, 파프리카의 수출 은 일본에 편중되어 있어 보다 안정적인 수출을 도모하기 위한 새로운 수출국의 확보가 필요한 실정이며 $(9,10)$, 원거 리 수송 시 파프리카의 높은 수분함량으로 인한 낮은 저장 성이 문제가 되고 있다. 또한 수확 후 저장 및 유통 동안에 호흡 및 증산작용 등의 생리적 대사가 활발해지며 여러 경로의 생화학적 과정을 통해 품질열화 현상이 일어나고 있다(11). 특히 흰곰팡이와 잿빛 곰팡이 등으로 인한 부패, 외관, 색, 향, 항산화 활성 등의 품질 저하는 장거리 유통 중 파프리카의 상품적 가치를 크게 떨어트리는 주요 요인이 되고 있다(12). 따라서 파프리카의 저장 및 유통 중 품질저 하를 방지하고 저장기간을 연장하기 위해 이산화염소 가스 훈증 처리(13), 비천공 필름 처리(14), MA 저장(10) 등의 연구가 보고되었다. 이와 함께 파프리카의 유통 및 저장 중 품질저하를 줄이기 위해서는 적합한 포장용기의 사용이 중요하지만, 이에 대한 연구가 매우 부족함에 따라 현재까 지 생산자나 유통업자의 경험에 따라 무분별하게 포장되고 있는 실정이다.

식품포장은 유통 과정에 있어서 식품의 보존성과 위생적 인 안정성을 높이고, 편의성과 보호성을 부여하는 기능이 있다(15). 식품공업이 발전하고 농산물의 유통량이 급증함 에 따라 원활한 운송 및 저장을 위해 골판지상자가 개발되 었고 현재에는 농산물 포장용으로 가장 많이 사용되고 있 다. 이러한 골판지상자는 접어서 보관할 수 있어 취급이 편리하고, 포장작업을 자동화 할 수 있으며, 자원의 재생 또는 재이용이 가능하고, 외부의 충격으로부터 내용물을 보호할 수 있는 특징이 있다(16). 하지만 포장 시 일반적으 로 이용되는 골판지상자는 유통 동안에 식품의 신선도 및 상품성 저하를 효과적으로 방지하기 어려우며, 식품의 수 분을 흡습함에 따라 강도가 저하되어 물리적 충격으로부터 의 보호성이 떨어지는 문제점이 있다(17). 이와 같은 골판지 상자의 문제점을 보완하기 위해서 상자 내부에 polyamide (PA)(18), low density polyethylene(LDPE)(19,20)과 같은 소 재의 기능성 필름을 코팅하여 농산물의 선도유지 효과를 평가하는 연구가 진행되었다. 앞선 연구에서 이용한 소재 이외에 널리 이용되는 식품 포장재 중 하나인 알루미늄은 무독, 무취, 무미이며 미관성, 방습성, 내수성, 내기성이 우 수한 장점을 가지고 있기 때문에 담배, 건식품, 과자 제품류 등의 포장에 이용되고 있지만(21), 현재까지 농산물의 포장 에 활용되지 않고 있다.

따라서 본 연구에서는 알루미늄을 골판지 상자 내부에 코팅하여 기능성 골판지 포장상자를 개발하였고, 이를 이 용하여 포장한 파프리카의 저장 중 이화학적 및 영양적 품질에 변화를 비교 조사함으로써 알루미늄 코팅 골판지상 자의 적합성과 효율성을 검토하였다.

\section{재료 및 방법}

\section{시료 및 포장재}

본 실험에 사용한 적색계 파프리카(Capsicum annum L.) 는 진주에서 2017년 6월에 수확한 것을 구매하여 사용하였 으며, 수확 직후 시료의 $\mathrm{pH}$ 와 ${ }^{\circ} \mathrm{Brix}$ 는 각각 $4.99 \pm 0.02$, $5.88 \pm 0.51$ 이었다. 포장용기는 진주 디자인팩에서 제작한 것을 제공받아 이용하였다. 골판지박스는 $\mathrm{A}$ 골로 제작하였 고 라이너 인쇄종이 $\mathrm{SC} 220$, 골심지 $\mathrm{K}$, 골심지 $\mathrm{Ck}$, 골심지 $\mathrm{K}$, 라이너 인쇄종이 백라이너 순으로 구성되어 있으며, 외 측과 내측의 크기는 각각 $270 \times 202 \times 150 \mathrm{~mm}, 265 \times 204 \times 145$ $\mathrm{mm}$ 으로 $5 \mathrm{~mm}$ 의 두께로 제조되었다. 골판지박스 내측에 알루미늄 증착필름을 접착한 후에 유광 라미네이팅 처리한 것을 알루미늄(Al) 코팅 골판지 포장재라고 하였고, 코팅하 지 않은 것을 대조구로 하였다.

\section{포장방법 및 저장조건}

적색계 파프리카는 외상이 없고 외피색이 유사하며 균일 한 무게 $(200 \pm 10 \mathrm{~g})$ 의 시료를 선별하여 사용하였다. 일반 골판지상자와 $\mathrm{Al}$ 코팅 골판지상자 안에 수확 직후의 파프 리카를 8 개씩 포장하였고, 이를 $25 \pm 0.5^{\circ} \mathrm{C}$ 온도의 배양기에 옮겨 5 일 간격으로 저장 중 품질변화를 측정하였다. 최종 저장기간은 전반적인 품질변화를 기준으로 과실의 상품적 가치가 남아있다고 판단되는 시점인 20일로 설정하였으며, 각 5 회 반복실험을 실시하였다.

\section{중량변화율}

파프리카의 중량변화율은 수확 직후 초기중량 $\left(\mathrm{W}_{0}\right)$ 을 기 준으로 저장 후 중량 $\left(\mathrm{W}_{\mathrm{t}}\right)$ 을 측정하여 얻은 중량손실에 대한 백분율 $(\Delta \mathrm{W})$ 로 나타내었다.

$$
\Delta \mathrm{W}(\%)=\mathrm{W}_{\mathrm{t}} / \mathrm{W}_{0} \times 100
$$

\section{경 도}

파프리카의 경도는 시료의 측면 중앙을 $1 \mathrm{~cm}$ 의 정사각형 모양으로 절단한 것을 Texture Analyzer(TA-XT Express, Micro Stable System, Surrey, UK)를 이용해 sharp blade cutting probe(길이 $75 \mathrm{~mm}$, 두께 $3 \mathrm{~mm}$ )를 장착하여 측정하 였다. 측정조건으로 trigger force는 $5.0 \mathrm{~g}$ 이었으며, pre-test, test, post test speed 모두 $1.0 \mathrm{~mm} / \mathrm{s}$ 로 설정하였고, 조건 당 25 회 반복 측정한 값을 평균하여 나타내었다.

\section{총 폴리페놀 함량}

파프리카의 총 페놀 함량을 분석하기 위하여 각 포장용 기 조건에서 저장기간에 따라 얻어진 파프리카를 액체질소 를 이용하여 급속동결하였고 이를 동결건조하여 분말화하 였다. 건조시료를 $80 \%$ 에탄올로 희석하고 균질기(D-500, 
Wiggen Hauser, Berlin, Germany)로 10,000 rpm에서 30초간 균질하였다. 이를 shaker(NB-303, n-Biotech, Incheon, $\mathrm{Korea}$ )를 이용하여 $200 \mathrm{rpm}$ 으로 $4^{\circ} \mathrm{C}$ 에서 2 시간 동안 추출 한 후 여과한 것을 실험에 사용하였다. 여과액 $1 \mathrm{~mL}$ 와 증류 수 $9 \mathrm{~mL}$ 를 혼합하여 $1 \mathrm{~mL}$ 의 Folin \& Ciocalteu's phenol reagent를 첨가한 후 실온 암실에서 5 분간 방치한다. 그 후 $7 \%$ sodium carbonate $10 \mathrm{~mL}$ 과 증류수 $4 \mathrm{~mL}$ 을 첨가하여 총량을 $25 \mathrm{~mL}$ 으로 하였다. 이를 실온 암실에 2 시간 동안 방치한 다음 분광광도계(UV-1800, Shimadzu Corporation, Kyoto, Japan)를 이용하여 $760 \mathrm{~nm}$ 에서 흡광도를 측정하였 으며, 총 페놀 함량은 g gallic acid equivalent(GAE)/kg dry weight(DW)로 나타내었다(22).

\section{항산화 활성}

파프리카의 항산화 활성을 분석하기 위하여 각 포장용기 조건에서 저장기간에 따라 얻어진 파프리카를 액체질소를 이용하여 급속동결하였고 이를 동결건조하여 분말화하였 다. 건조시료를 $80 \%$ 에탄올로 희석하고 균질기로 10,000 $\mathrm{rpm}$ 에서 30초간 균질하였다. 이를 shaker를 이용하여 200 $\mathrm{rpm}$ 으로 $4^{\circ} \mathrm{C}$ 에서 2 시간 동안 추출한 후 여과한 것을 실험에 사용하였다.

2,2-diphenyl-1-picrylhydrazyl(DPPH) 라디컬 소거 활성 은 Blois(23)의 방법을 변형하여 실험을 진행하였다. 100 $\mathrm{mL}$ 의 에탄올에 $8 \mathrm{mg}$ 의 DPPH를 용해시켜 DPPH 원액을 제조하였다. 여과액 $0.1 \mathrm{~mL}$ 은 DPPH 용액(OD:1.000) 0.9 $\mathrm{mL}$ 과 혼합하여 실온 암실에서 30 분간 방치 후 분광광도계 (UV-1800, Shimadzu Corporation, Kyoto, Japan)를 이용하여 $517 \mathrm{~nm}$ 에서 흡광도를 측정하였으며, 이를 $\mathrm{g}$ butylated hydroxyanisole equivalent(BHAE)/kg DW로 나타내었다.

2,2'-azino-bis(3-ethylbenzthiazoline-6-sulfonic acid)(ABTS) 라디컬 소거능은 Re 등(24)의 방법을 변형하 여 실험을 진행하였다. $\mathrm{ABTS}$ 용액은 $7 \mathrm{mM} \mathrm{ABTS}$ diammonium salt와 $2.45 \mathrm{mM}$ potassium persulphate를 혼합 후 실온 암실에서 16 시간 동안 방치하여 제조하였다. 여과 액 $20 \mu \mathrm{L}$ 와 ABTS 용액 $980 \mu \mathrm{L}$ 를 혼합 후 실온 암실에서 6분 동안 방치한 후 분광광도계를 이용하여 $734 \mathrm{~nm}$ 에서 흡광도를 측정하였다. ABTS 라디컬 소거능은 $\mathrm{g}$ ascorbic acid equivalent(AAE) $/ \mathrm{kg}$ DW로 나타내었다.

FRAP(ferric ion reducing antioxidant power) 측정은 Benzie와 Strain(25)의 방법을 변형하여 실험을 진행하였다. 즉 $300 \mathrm{mM}$ sodium acetate buffer(pH 3.6)와 $40 \mathrm{mM} \mathrm{HCl}$ 로 용해시킨 $10 \mathrm{mM}$ trpydyltriazine(TPTZ), $20 \mathrm{mM} \mathrm{FeCl} \cdot 6 \mathrm{H}_{2} \mathrm{O}$ 을 제조하였고, 이를 각각 10:1:1 (v/v/v) 비율로 혼합하여 FRAP 용액을 제조하였다. 여과액 $50 \mu \mathrm{L}$ 와 FRAP 용액 $1.5 \mathrm{~mL}$ 를 혼합 후 실온 암실에서 30 분간 방치한 후 분광광 도계를 이용하여 $593 \mathrm{~nm}$ 에서 흡광도를 측정하였다. FRAP 환원력은 $\mathrm{g} \mathrm{Fe}(\Pi) / \mathrm{kg} \mathrm{DW}$ 로 나타내었다.

\section{펙틴분해효소 활성}

파프리카의 펙틴분해효소 활성을 알아보기 위하여, 시료 의 polygalacturonase(PG) 활성을 Srivastava과 Dwivedi(26) 의 방법으로 측정하였다. $\mathrm{PG}$ 는 $1 \mathrm{~g}$ 의 분쇄한 시료에 cysteine-HCl(0.02 M), EDTA(0.02 M), Triton X-100(0.05\%) 이 용해된 sodium phosphate buffer(0.02 M, pH 7.0) $10 \mathrm{~mL}$ 를 넣은 후 균질기로 $10,000 \mathrm{rpm}$ 에서 30 초간 균질하였다. 이를 shaker를 이용하여 $200 \mathrm{rpm}$ 으로 $4^{\circ} \mathrm{C}$ 에서 2 시간 동안 추출한 후 이를 여과하여 효소용액으로 사용하였다. 기질용액은 $0.02 \mathrm{M}$ sodium acetate buffer( $\mathrm{pH} 4.5)$ 에 $1 \%$ polygalacturonic acid를 용해하여 사용하였다. 효소용액 $0.15 \mathrm{~mL}$ 와 기질용액 $0.6 \mathrm{~mL}$ 를 혼합하여 $37^{\circ} \mathrm{C}$ 에서 1 시간 동안 반응시킨 후 100 $\mathrm{mM}$ sodium tetraborate decahydrate과 $100 \mathrm{mM}$ boric acid이 용해된 용액 $2 \mathrm{~mL}$ 과 $1 \%$ cyanoacetamide $0.4 \mathrm{~mL}$ 을 첨가하여 반응을 정지시켰다. 이를 $100^{\circ} \mathrm{C}$ 에서 10 분간 가열하여 실온 에서 냉각한 후 $276 \mathrm{~mm}$ 에서 흡광도를 측정하여 $\mathrm{D}$-galacturonic acid의 양을 측정하였다. 펙틴분해효소 활성 은 $37^{\circ} \mathrm{C}$ 에서 1 분간 $1 \mu \mathrm{mol}$ 의 D-galacturonic acid를 생성하는 것을 1 unit으로 하였다.

\section{산화효소 활성}

파프리카의 산화효소 활성을 알아보기 위하여, 과채류의 주요 산화효소인 polyphenol oxidase(PPO)와 peroxidase (POD) 활성을 측정하였고, 효소추출은 Eshghi 등(27)의 방 법을 변형하여 실험에 사용하였으며, 효소활성은 Terefe 등(28)의 방법을 참고하여 측정하였다. $\mathrm{PPO}$ 와 $\mathrm{POD}$ 의 추출 은 4\% (w/v) poly(vinylpolypyrrolidone), $1 \%$ (w/v) Triton $\mathrm{X}-100,1 \mathrm{M} \mathrm{NaCl}$ 이 용해된 $0.2 \mathrm{M}$ sodium phosphate buffer(pH 6.5) $10 \mathrm{~mL}$ 에 동결건조 시료 $0.2 \mathrm{~g}$ 을 가한 후 균질기로 $10,000 \mathrm{rpm}$ 에서 30 초간 균질하였다. 이를 shaker 를 이용하여 $200 \mathrm{rpm}$ 으로 $4^{\circ} \mathrm{C}$ 에서 2 시간 동안 추출한 후 이를 여과하여 효소용액으로 사용하였다. PPO 활성 측정시 사용되는 기질용액은 $0.05 \mathrm{M}$ sodium phosphate buffer( $\mathrm{pH}$ 6.5)에 $0.07 \mathrm{M}$ catechol를 용해하여 제조하였다. 효소용액 $75 \mu \mathrm{L}$ 에 기질용액 $3 \mathrm{~mL}$ 를 첨가한 후 분광광도계의 kinetic mode를 이용하여 $420 \mathrm{~nm}$ 에서 10 분 동안 흡광도의 변화를 측정하였다. POD 활성은 $200 \mu \mathrm{L}$ 의 효소용액에 $1.5 \mathrm{~mL}$ 의 $0.05 \mathrm{M}$ sodium phosphate buffer(pH 6.5), $200 \mu \mathrm{L}$ 의 $1 \%$ p-phenylenediamin이 용해된 $0.05 \mathrm{M}$ sodium phosphate buffer(pH 6.5), $200 \mu \mathrm{L}$ 의 1.5\% hydrogen peroxide가 용해된 $0.05 \mathrm{M}$ sodium phosphate buffer( $\mathrm{pH}$ 6.5)를 첨가하여 분광광 도계의 kinetic mode를 이용하여 $482 \mathrm{~nm}$ 에서 10 분 동안 흡광도의 변화를 측정하였다. 모든 추출용액과 기질용액은 분석 직전에 제조하여 사용하였고, 산화효소 활성 1 unit은 효소 추출액의 1 분당 0.001 의 흡광도의 변화인 $\mathrm{U} / \mathrm{g} / \mathrm{min}$ 으 로 나타내었다. 


\section{통계분석}

실험 결과는 반복 실험하여 얻어진 평균표준편차로 나 타내었고, 통계처리는 Window용 SAS 9.4 version(SAS Institute Inc., Cary, NC, USA)을 이용하여 p $<0.05$ 수준에서 분산분석(analysis of variance)을 실시하였으며, Duncan의 다중범위 검정법(Duncan's multiple range test)으로 유의성 을 검증하였다.

\section{결과 및 고찰}

\section{중량변화율}

과채류의 유통 저장 중 중량감소는 증산과 호흡작용, 수 분증발에 의한 것이며, 이는 조직 연화와 같은 외형 변화를 일으켜 상품성 저하를 초래하는 주요 요소이다(29). 따라서 일반 골판지상자와 알루미늄(Al) 코팅한 골판지상자에 포 장 후 저장한 파프리카의 중량변화율을 측정하였으며, 그 결과는 Fig. 1 과 같다. 저장 5 일과 20 일 후 일반 골판지상자 에 포장한 파프리카의 중량은 각각 $6.73 \%$ 와 $24.81 \%$ 수준으 로 감소하였으며, $\mathrm{Al}$ 코팅 골판지상자에 포장한 파프리카 의 중량은 각각 $0.46 \%$ 와 $2.90 \%$ 수준으로 감소하였다. 따라 서 저장기간 동안 일반 골판지상자에 포장한 파프리카의 중량손실이 매우 급격하게 일어난 것과 달리 $\mathrm{Al}$ 코팅 골판 지상자의 중량감소는 매우 적은 것으로 나타났다. Costa 등(30)은 과채류의 중량감소는 표면을 둘러싸고 있는 세포 막 조직의 변화를 나타내며, 이 세포막은 과실의 수분 감소 를 막고 호흡을 통한 가스교환을 조절하는 역할을 한다고 보고하였다. Jung 등(31)은 기체투과도가 낮은 포장재로 포장한 딸기의 경우 저장 중 외부로부터 공기의 유입을 막기 때문에 포장재 내부의 산소 농도가 매우 감소하고 호흡률이 낮아짐으로써 중량감소가 적게 일어난다고 보고 하였고, $\operatorname{Kim}$ 과 $\operatorname{Kim}(32)$ 은 알루미늄박으로 소엽과 박하를 포장했을 때 수분함량의 변화를 최소화시킬 수 있다고 보고 하였다. 또한, Moon(21)은 알루미늄박은 내기성 및 방습성 이 매우 우수하여 외부 환경과의 접촉을 차단시킨다고 보고 하였다. 결과적으로, 골판지상자 내측의 알루미늄 코팅은 내부공기의 확산과 외부공기의 유입을 차단시킴으로써 저 장 중 파프리카의 호흡에 의한 조직의 분해와 수분 증발을 효과적으로 방지할 수 있다고 생각된다. 또한 파프리카의 경우 상품성이 유지되는 중량감소 허용범위는 $4 \%$ 수준으 로(33), 일반 골판지상자에 포장된 파프리카는 중량감소율 측면에서 저장 5 일 만에 상품적 가치가 없었으며, $\mathrm{Al}$ 코팅 골판지상자에 포장한 파프리카의 경우 저장 20 일 동안 적 합한 상품성을 유지하는 것으로 나타났다.

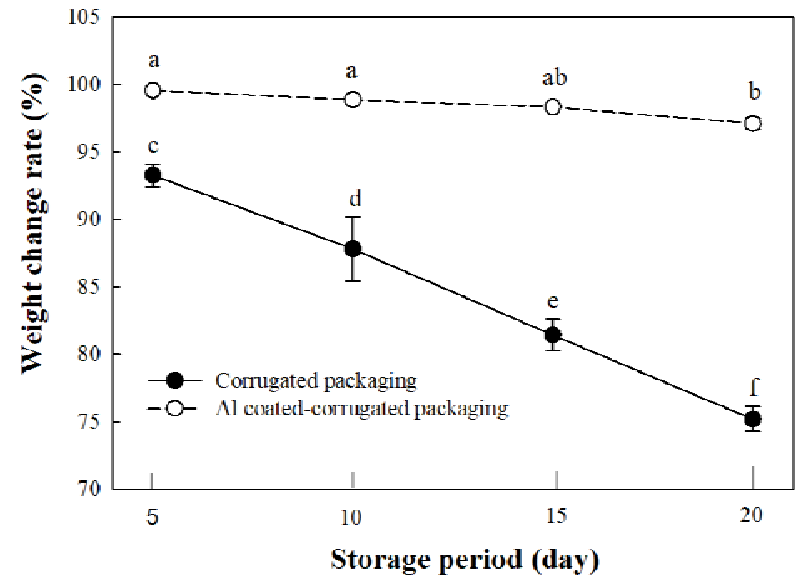

Fig. 1. Change in weight loss of paprika during storage at $25^{\circ} \mathrm{C}$, under corrugated packaging or Al-coated corrugated packaging.

\section{경 도}

유통 저장 중 파프리카의 신선도를 평가하는 물리적 방 법 중 대표적으로 과육의 경도를 측정할 수 있으며, 이는 저장성에 큰 영향을 주는 것으로 알려져 있다(18). 따라서 일반 골판지상자와 $\mathrm{Al}$ 코팅 골판지상자에 포장 후 저장한 파프리카의 경도를 측정하였으며, 그 결과는 $\mathrm{Fig} 2$ 와 같다. 수확 직후 파프리카의 경도는 $405.55 \mathrm{~g}$ 이었으며, 저장 15 일 후 일반 골판지상자와 $\mathrm{Al}$ 코팅된 골판지상자에 포장된 파 프리카의 경도는 각각 $253.03 \mathrm{~g}, 342.04 \mathrm{~g}$ 수준으로 나타났 고, 대조구와 처리구 모두 저장기간이 길어질수록 경도가 감소하는 경향을 보였다. 이와 같이 저장 중 일어나는 과채 류의 경도 저하의 주원인은 수확 후 계속되는 호흡작용에 의한 세포벽 분해효소인 polygalacturonase의 작용과 $\beta$ -galactosidase의 분해에 따른 세포벽 구성성분들의 변화 및 세포벽 파괴에 의한 것으로 알려져 있다(34). 또한 모든 저장기간 동안 $\mathrm{Al}$ 코팅 골판지상자에 포장된 파프리카는 일반 골판지상자에 포장된 파프리카 보다 높은 경도를 가지

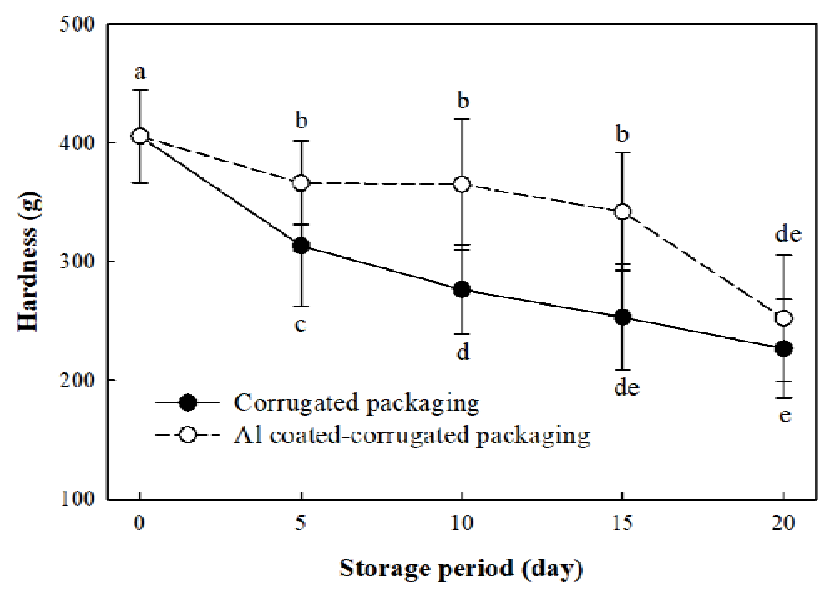

Fig. 2. Change in hardness of paprika during storage at $25^{\circ} \mathrm{C}$, under corrugated packaging or Al-coated corrugated packaging. 
는 것으로 나타났으며, 저장 5 일에서 15 일 동안 경도의 유의 적 감소가 없었다. Choi 등(9)은 기체투과도가 낮은 포장재 로 파프리카를 포장 후 저장하였을 때 그것의 호흡작용에 의해 내부 산소 농도가 낮아지고 이산화탄소 농도가 높아졌 으며, 이에 따라 낮아진 호흡률에 의해 중량손실은 적었으 며, 경도는 높게 유지된다고 보고하였다. 따라서 $\mathrm{Al}$ 코팅은 외부의 기체투과도를 감소시켜 호흡작용을 저해시킴으로 써 파프리카의 세포벽 파괴를 방지하여 경도가 상대적으로 높게 유지되는 것으로 생각된다.

\section{총 폴리페놀 함량 및 항산화 활성}

파프리카는 카로티노이드, 비타민C, 토코페롤, 페놀화합 물와 같은 파이토케미컬이 풍부하게 함유되어 있으며, 이 로 인한 높은 항산화능으로 인해 고품질 작물로 알려져 있다(3-7). 따라서 일반 골판지상자와 $\mathrm{Al}$ 코팅 골판지상자 에 포장 후 저장기간 동안 파프리카의 총 페놀 함량 및 항산화 활성을 측정하였으며, 그 결과는 Fig. 3 과 같다. 모든 저장기간 동안에 총 페놀 함량 및 항산화 활성 측정 결과에 서 $\mathrm{Al}$ 코팅 골판지상자에 포장된 파프리카는 일반 골판지 상자에 포장된 파프리카보다 높은 함량 및 활성을 가지는 것으로 나타났다. 특히, 저장 15 일 후 골판지상자 내부에 $\mathrm{Al}$ 을 코팅함으로써 파프리카의 총 페놀 함량, DPPH 라디컬 소거능, $\mathrm{ABTS}$ 라디컬 소거능, FRAP 결과 값이 일반 골판지 상자에 비해 각각 $2.44,2.82,3.16,2.79$ 배 상승한 것으로 나타났다. Fernandez-Leon 등(35)과 Oliveira 등(36)은 호흡 작용을 하는 과채류의 경우 기체투과도가 낮은 포장재를 이용하여 포장 및 저장했을 때 더 높은 총 페놀 함량과 항산화 활성을 유지할 수 있고, 이에 따라 유통기한 연장에 효과적이라고 보고하였다. $\mathrm{Hu}$ 등(37)은 외부로부터의 수분 투과와 산소 유입을 방지할 수 있는 포장재로 포장된 키위 는 일반 포장된 키위보다 저장기간 동안 높은 총 페놀 함량 을 유지하였다고 보고하였다.

저장기간에 따라 총 페놀 함량 및 항산화 활성이 감소하 는 일반 골판지상자와 달리, $\mathrm{Al}$ 코팅 골판지상자에 포장된 파프리카의 총 페놀 함량 및 항산화 활성은 저장 10 일 이후 부터 다소 감소하는 경향을 가지는 것으로 나타났다. 반면, 10 일까지의 저장기간 동안에는 총 페놀 함량과 $\mathrm{ABTS}$ 라디 컬 소거능은 증가하였으나, DPPH 라디컬 소거능은 다소 감소하는 것으로 나타났다. 이러한 결과는 $\mathrm{ABTS}$ 분석법의 경우 수용성과 지용성 항산화제의 활성을 모두 측정할 수 있지만, DPPH 분석법은 수용성 항산화제 분석에 제한적인 측정방법으로 알려져 있다(38). 따라서 저장 10 일 동안 파프 리카 내의 지용성 항산화 물질은 다소 감소하지만 폴리페놀 화합물과 수용성 항산화 물질은 증가한 것으로 추측된다. Raffo 등(39)은 $8^{\circ} \mathrm{C}$ 에서 저장한 적색계 파프리카는 성숙이 진행됨에 따라 6 일까지 총 플라보노이드 함량이 증가하였 고, 6 일 이후에 함량이 감소했다고 보고하였다. Cha 등(40)
은 미숙과에서 완숙과로 성숙하면서 총 폴리페놀 화합물이 증가한다고 보고하였으며, 이러한 결과는 성숙 과정 동안 에 과실의 2 차 대사산물의 생성에 의한 것으로 생각된다. 또한 Wilkinson 등(41)은 계속되는 과실의 성숙은 과실내의 페놀화합물이 다른 물질과 결합하여 페놀과는 형태가 다른 물질로 과실 내에 축적되었기 때문이라고 보고하였다. 결 과적으로 골판지상자 내부의 $\mathrm{Al}$ 코팅은 파프리카의 총 페 놀 함량 및 항산화 활성이 감소되는 것을 저해함으로써 저장 유통 동안의 영양적 가치를 유지시키는 것에 이바지할 수 있을 것이라 생각된다.

\section{펙틴분해효소 및 산화효소 활성}

파프리카의 숙성과 저장 중에 세포벽 분해효소인 polygalacturonase $(\mathrm{PG})$ 의 활성이 증가하고, 세포벽이 분해 되어 조직 연화가 일어나게 된다(42). 따라서 일반 골판지상 자와 $\mathrm{Al}$ 코팅 골판지상자에 포장 후 저장기간 동안 파프리 카의 PG 활성을 측정하였으며, 그 결과는 Table 1 과 같다. 대조구와 처리구 모두 저장기간에 따라 $\mathrm{PG}$ 활성이 증가하 는 것으로 나타났으며, 저장기간 동안에 일반 골판지상자 에 포장한 파프리카는 $\mathrm{Al}$ 코팅 골판지상자에 포장한 파프 리카보다 더 높은 PG 활성을 가지는 것으로 나타났다. 이와 유사한 연구결과로, Nakhasi 등(43)은 토마토를 기체투과성 이 낮은 polymeric film으로 포장했을 때 낮은 산소 농도로 인하여 PG activity가 저해되며, 따라서 중량감소와 경도의 저하를 지연시킬 수 있다고 보고하였다. 따라서 골판지상 자 내부의 $\mathrm{Al}$ 코팅은 그것의 높은 방습성과 낮은 기체투과 성을 부여함으로써, 파프리카의 $\mathrm{PG}$ 활성을 저해시키고 조 직 연화를 억제하여 경도를 높게 유지시키는 것으로 판단된 다. 또한 일반 골판지상자와 $\mathrm{Al}$ 코팅 골판지상자에 저장한

Table 1. Changes in polygalacturonase (PG) activity and oxidative enzyme activity such as polyphenol oxidase (PPO) and peroxidase (POD) of paprika during storage at $25^{\circ} \mathrm{C}$, under corrugated packaging or Al-coated corrugated packaging

\begin{tabular}{ccccc}
\hline \multirow{2}{*}{$\begin{array}{c}\text { Packaging } \\
\text { container }\end{array}$} & \multirow{2}{*}{$\begin{array}{c}\text { Storage day } \\
\text { (day) }\end{array}$} & \multicolumn{3}{c}{ Enzyme activity (U/g/min) } \\
\cline { 3 - 5 } Before packaging & 0 & $42.13 \pm 1.18^{\mathrm{el})}$ & $35.98 \pm 6.60^{\mathrm{bc}}$ & $284.93 \pm 46.43^{\mathrm{ab}}$ \\
& 5 & $46.86 \pm 1.91^{\mathrm{bc}}$ & $39.01 \pm 8.60^{\mathrm{bc}}$ & $302.66 \pm 28.63^{\mathrm{ab}}$ \\
& 10 & $47.22 \pm 1.37^{\mathrm{b}}$ & $44.76 \pm 7.66^{\mathrm{ab}}$ & $269.72 \pm 22.57^{\mathrm{b}}$ \\
Corrugated packaging & 15 & $49.88 \pm 1.75^{\mathrm{a}}$ & $51.29 \pm 7.13^{\mathrm{a}}$ & $351.03 \pm 44.92^{\mathrm{a}}$ \\
& 20 & $51.22 \pm 1.37^{\mathrm{a}}$ & $50.08 \pm 8.34^{\mathrm{a}}$ & $275.31 \pm 28.18^{\mathrm{ab}}$ \\
& 5 & $44.08 \pm 1.07^{\text {de }}$ & $36.38 \pm 10.56^{\mathrm{c}}$ & $293.72 \pm 34.77^{\mathrm{ab}}$ \\
Al coated- & 10 & $44.41 \pm 1.84^{\mathrm{cde}}$ & $36.00 \pm 9.51^{\mathrm{bc}}$ & $261.73 \pm 34.17^{\mathrm{b}}$ \\
corrugated packaging & 15 & $45.03 \pm 1.52^{\mathrm{bcd}}$ & $42.39 \pm 5.02^{\mathrm{abc}}$ & $290.28 \pm 33.06^{\mathrm{ab}}$ \\
& 20 & $47.08 \pm 1.39^{\mathrm{b}}$ & $35.94 \pm 5.46^{\mathrm{bc}}$ & $258.75 \pm 37.02^{\mathrm{b}}$ \\
\hline
\end{tabular}

${ }^{1)}$ All values are mean $\pm \mathrm{SD}(\mathrm{n}=3)$. Means with different letter superscripts in the same column for the same packaging are significantly different $(\mathrm{p}<0.05)$ by Duncan's multiple range test. 
파프리카의 $\mathrm{PG}$ 활성은 각각 저장 5 일과 20 일에서 가장 크게 증가한 것으로 나타났고, 이는 조직 연화가 가장 현저 히 진행된 시기로 경도의 감소와 일치하는 결과(Fig. 2)를 발견할 수 있었다.

과채류의 polyphenol oxidase(PPO)와 peroxidase(POD)는 산소 존재 하에서 페놀 화합물을 산화를 유도하는 대표적인 산화효소이다(44). 따라서 일반 골판지상자와 $\mathrm{Al}$ 코팅 골판 지상자에 포장 후 저장기간 동안 파프리카의 PPO 활성 및 $\mathrm{POD}$ 활성을 측정하였으며, 그 결과는 Table 1 과 같다. 일반 골판지상자와 $\mathrm{Al}$ 코팅 골판지상자에 포장한 파프리카 모두 저장 15 일까지 산화효소 활성이 증가하였고, 저장 20 일에 활성이 감소하는 경향을 보였다. 또한 $\mathrm{Al}$ 코팅 골판지 상자에 포장한 파프리카가 일반 골판지상자에 포장한 파프 리카보다 저장기간 동안 더 낮은 활성을 가지는 것으로 나타났다. $\mathrm{Hu}$ 등(37)은 외부로부터의 수분 투과와 산소 유 입을 방지할 수 있는 포장재를 이용하여 PPO 활성을 저해 함에 따라 페놀릭 화합물을의 산화를 방지함으로써 수확 후 저장 동안의 키위의 품질을 비교적 높게 유지할 수 있다 고 보고하였다. 또한 Marsh와 Bugusu(45)은 알루미늄은 외

(A)

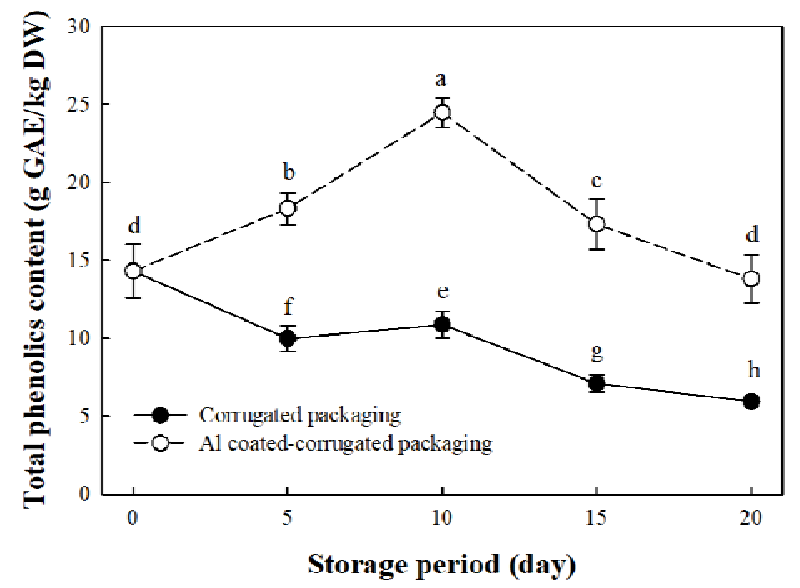

(C)

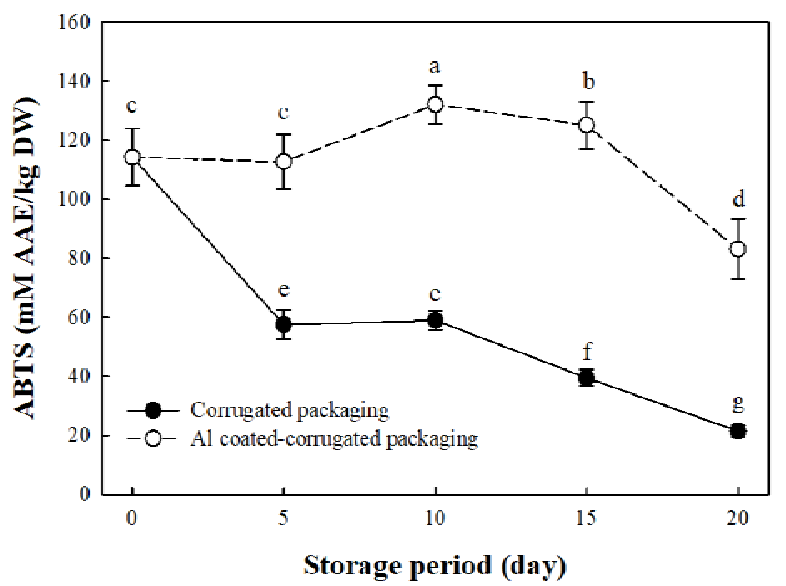

부로부터 공기, 빛, 수분을 차단할 수 있는 우수한 포장재로 식품산업에 많이 활용되고 있다고 보고하였다. 결과적으 로, 골판지상자 내부에 $\mathrm{Al}$ 코팅은 파프리카의 산화효소인 $\mathrm{PPO}$ 와 $\mathrm{POD}$ 활성을 저해시켜 저장 중 더 높은 총 페놀 함량 및 항산화 활성을 유지하는데 도움을 주는 것으로 생각된다(Fig. 3).

\section{요 약}

파프리카는 우리나라의 대표적인 수출작물로 알려져 있 지만 장거리 유통 중 일어나는 품질열화로 인해 상품적 가치가 감소되는 문제가 있다. 따라서 본 연구는 농산물 유통 시 주로 사용되는 골판지상자의 내부에 알루미늄을 코팅하여 기능성을 부여한 포장용기를 개발하였으며, 이를 이용하여 파프리카를 포장하여 저장 중 선도유지 및 품질특 성에 미치는 영향을 알아보았다. 골판지상자 내부에 알루 미늄을 코팅함으로써 방습성을 향상시키고 기체투과도를 저하시킴으로써 포장된 파프리카의 펙틴분해효소 활성이

(B)

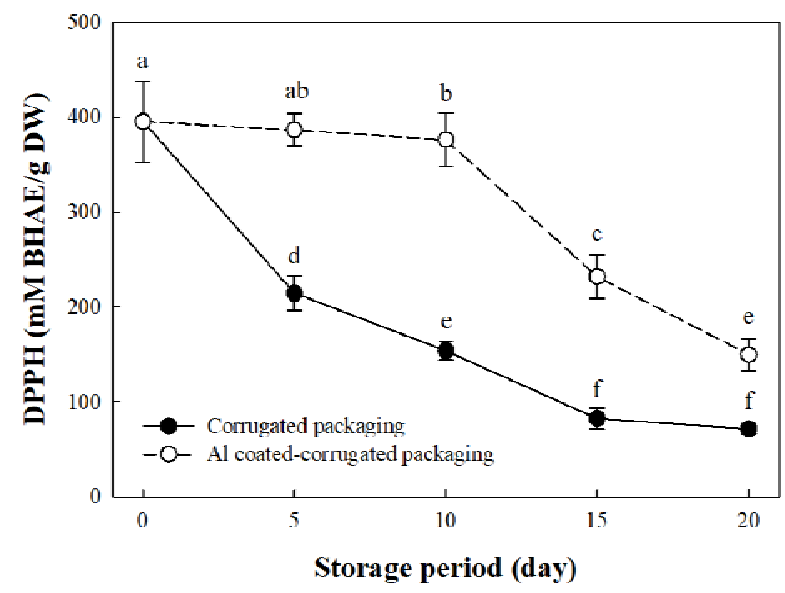

(D)

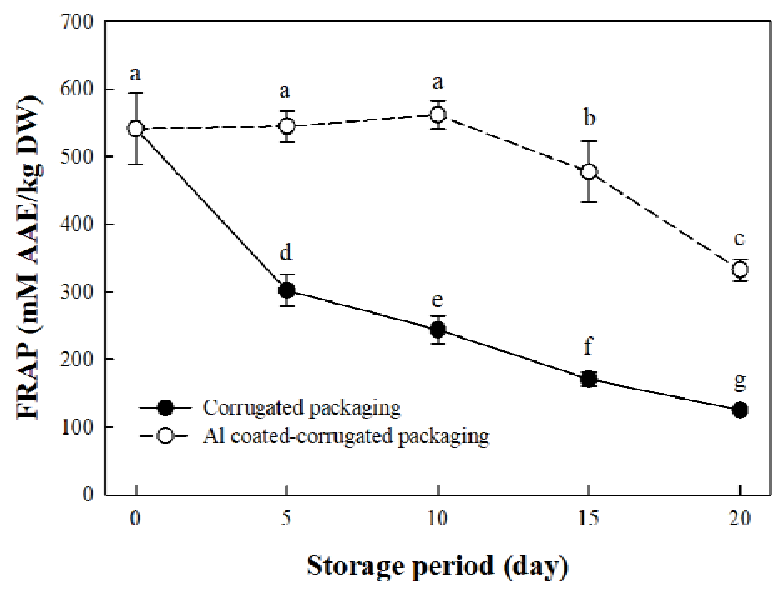

Fig. 3. Changes in total phenolic content (A), DPPH radical scavenging activity (B), FRAP assay (C), and ABTS radical scavenging activity (D) of paprika during storage at $25^{\circ} \mathrm{C}$, under corrugated packaging or Al-coated corrugated packaging. 
저하됨에 따라 파프리카의 중량변화율과 조직연화 현상이 저해되었고, 산화효소 활성이 감소함으로써 총 페놀 함량 및 항산화 활성이 향상되는 것으로 나타났다. 결과적으로 알루미늄 코팅한 골판지상자는 파프리카의 상품성 및 저장 성을 향상시키는 포장용기로 이용될 수 있을 것으로 생각되 며, 알루미늄박의 내수성, 내한성, 보향성, 내오염성 등의 특성을 활용한 추가연구를 통해 국내 농산물의 장거리 유통 및 수출 활성화에 이바지할 수 있을 것이라 생각된다.

\section{감사의 글}

본 연구는 중소기업청 2016년도 산학연협력 기술개발사 업(No. 2016-1038)의 지원에 의해 수행되었으며 이에 감사 드립니다.

\section{References}

1. Lee SO, Lee SK, Kyung SH, Park KD, Kang HG, Park JS (2002) A study on detection of residual solvent, ethoxyquin and color stability in oleoresin paprika extracts. J Korean Soc Agric Chem Biotechnol, 45, 77-83

2. Lee JW (2001) Present condition of paprika cultivation and its prospects for export. Kor Res Soc Protected Hort, $14,36-41$

3. Colditz GA (1987) Contributions of fruits and vegetables. In : Quebedeaux, Horticulture and Human Health, Bliss FA (Editor), ASHS Symposium Series No. 1, PrenticeHall, Upper Saddle River, NJ, USA, p 150-159

4. Krinsky NI, Johnson EJ (2005) Carotenoid actions and their relation to health and disease. Mol Aspects Med, 26, 459-516

5. Seddon JM, Ajani UA, Sperduto RD, Hiller R, Blair N, Burton TC, Farber MD, Gragoudas ES, Haller J, Miller DT, Yannuzi LA, Willet W (1994) Dietary carotenoids, vitamins $\mathrm{A}, \mathrm{C}$, and $\mathrm{E}$, and advanced age-related macular degeneration. J Am Med Assoc, 272, 1413-1420

6. Voutilainen S, Nurmi T, Mursu J, Rissanen TH (20006) Carotenoids and cardiovascular health. Am J Clin Nutr, 83, 1265-1271

7. Jeong CH, Ko WH, Cho JR, Ahn CG, Shim KH (2006) Chemical components of Korean paprika according to cultivars. Korean J Food Preserv, 13, 43-49

8. Ministry for food, agriculture, forestry and fisheries (MIFAFF) Korea (2009) Crop production statistics. Seoul, Korea
9. Choi IL, Yoo TJ, Kim IS, Lee YB, Kang HM (2011) Effect of non-perforated breathable films on the quality and shelf life of paprika during MA storage in simulated long distance export condition. J Bio-Environ Control, 20, 150-155

10. Choi IL, Lee YB, Kim IS, Kang HM (2012) A comparison of the storability in MA storage and the quality of paprika fruit among cultivars. J Bio-Environ Control, 21, 252-260

11. Suh DW (1998) Effect of hypoxia stress on fermented-fruit of oriental melon (Cucumis melo L. var. makuwa Makino). RDA J Horti Sci, 40, 61-65

12. Hong HJ, Kim AJ, Park HR, Shin JK (2013) Changes in physicochemical properties of paprika by intense pulsed light treatment. Korean J Food Sci Technol, 45, 339-344

13. Kang JH, Par SM, Kim HG, Son HJ, Song KJ, Cho M, Kim JR, Lee JY, Song KB (2015) Gaseous chlorine dioxide treatment to produce high quality paprika for export. J Korean Soc Food Sci Nutr, 44, 1072-1078

14. Choi IL, Yoo TJ, Kim IS, Lee YB Kang HM (2011) Effect of non-perforated breathable films on the quality and shelf life of paprika during MA storage in simulated long distance export condition. J Bio-Envion Control, 20, $150-155$

15. Lee JH (1998) Shelf life and nutrition of packed food. Food Science and Industry, 3, 8-13

16. Park JB (1990) Corrugated cardboard and corrugated packaging box. Food Sci Ind, 12, 53-64

17. Jo JY, Min CK, Shin JW (2004) Manufacture of water-resistant corrugated board boxes for agricultural products in the cold chain system(II)-application methods of chemicals for improving water and moisture resistance of corrugated boards-. J Korea TAPPI, 4, 192-210

18. Cha HS, Lee SA, Kwon KH, Kim BS, Choi DJ, Youn AR (2013) Effets of the initial storage temperature of a PA film-packaged muskmelon (Cucumismelo L.) during its storage. Korean J Food Preserv, 20, 14-22

19. Park HW, Kim DM (2000) Effect of functional MA packaging film on freshness extension of 'fuji' apples. J Korean Soc Food Sci Nutr, 29, 80-84

20. Park HW, Kim DM, Kim SH, Park JD, Kim KJ (1998) Freshness preserving of 'Shingo' Pear using corrugated paperboard box laminated with functional MA film. Korean J Postharvest Sci Technol, 5, 335-338

21. Moon HJ (1983) Aluminim foil. Food Science and Industry, 5, 45-48

22. Singleton VL, Rossi JA (1965) Colorimetry of total 
phenolic with phosphomolybdic-phosphotungstic acid reagents. Am J Enol Vitic, 16, 144-158

23. Blois MA (1958) Antioxidant determination by the use of a stable free radical. Nature, 181, 1199-1200

24. Re R, Pellegrini N, Proteggente A, Pannala A, Yang M, Rice-Evans C (1999) Antioxidant activity applying an improved ABTS radical cation decolorization assay. Free Radical Biol Med, 26, 1231-1237

25. Benzie IFF, Strain JJ (1996) The ferric reducing ability of plasma as a measure of "antioxidant power": the FRAP assay. Anal Biochem, 239, 70-76

26. Srivastava MK, Dwivedi UN (1998) Salicylic acid modulates glutathione metabolism in pea seedlings. $\mathrm{J}$ Plant Physiol, 153, 409-414

27. Eshghi S, Hashemi M, Mohammadi A, Badii F, Mohammadhoseini Z, Ahmadi K (2014) Effect of nanochitosan-based coating with and without copper loaded on physicochemical and bioactive components of fresh strawberry fruit (Fragaria $\times$ ananassa Duchesne) during storage. Food Bioprocess Tech, 7, 2397-2409

28. Terefe NS, Matthies K, Simons L, Versteeg C (2009) Combined high pressure-mild temperature processing for optimal retention of physical and nutritional quality of strawberries (Fragaria $\times$ ananassa). Innovative Food Sci Emerging Technol, 10, 297-307

29. Kader AA (2002) Postharvest technology of horticultural crops $3^{\text {rd }}$ edition. University of California Agriculture and Natural Resources, California, USA

30. Costa C, Lucera A, Conte A, Mastromatteo M, Speranza B, Antonacci A, Del Nobile MA (2011) Effects of passive and active modified atmosphere packaging conditions on ready to eat table grape. J Food Eng, 102, 115-121

31. Jung SH, Kang JH, Park SJ, Seong KH, Song KB (2014) Quality Changes in 'Elliot' blueberries and 'Sulhyang' strawberries packed with two different packaging materials during refrigerated storage. J Korean Soc Food Sci Nutr, 43, 901-908

32. Kim SM, Kim EJ (2009) Studies on storage characteristics of Perilla Perfrutescens var. Acuta, Mentha Arvensis L. var. Piperascens Malinvaud according to packaging method. Korea J Herbology, 24, 9-14

33. Kays SJ, Paull RE (2004) Postharvest Biology. Exon Press, Athens, GA, USA, p 568

34. Hobson GE (1981) Enzymes and texture change during ripening. In: Recent Advances in the Biochemistry of Fruit and Vegetables, Friend J, Rhodes MJC (Editors),
Academic Press, London, UK, p 123-132

35. Fernandez-Leon MF, Fernandez-Leon AM, Lozano M, Ayuso MC, Amodio ML, Colelli G, Gonzalez-Gomez D (2013) Retention of quality and functional values of broccoli 'Parthenon' stored in modified atmosphere packaging. Food Control, 31, 302-313

36. Oliveira FAR, Fonseca SC Oliveira JC, Brecht JK, Chau KV (1998) Development of perforation-mediated modified atmosphere packaging to preserve fresh fruit and vegetable quality after harvest. Food Sci Technol Int, 4, 339-352

37. Hu Q, Fang Y, Yang Y, Ma N, Zhao L (2011) Effect of nanocomposite-based packaging on postharvest quality of ethylene-treated kiwifruit (Actinidia deliciosa) during cold storage. Food Res Int, 44, 1589-1596

38. Park TS, Lee SY, Kim HJ, Kim KT, Kim YJ, Jeong IH, Do WN, Lee HJ (2009) Extracts of adlay, barley and rice bran have antioxidant activity and modulate fatty acid metabolism in adipocytes. Korean J Food Nutr, 22, 456-462

39. Raffo A, Baiamonte I, Paoletti F (2008) Changes in antioxidants and taste-related compounds content during cold storage of fresh-cut red sweet peppers. 226, 1167-1174

40. Cha HS, Youn AR, Park PJ, Choi HR, Kim BS (2007) Comparison of physiological activities of Rubus coreanus Miquel during maturation. 36(6), 683-688

41. Wilkinson BG (1970) Physiological disorders of fruit after harvesting. In: The Biochemistry of Fruit and Products, Hulme AC (Editor), Academic Press, New York, NY, USA, p 537-553

42. Hobson GE (1981) Enzymes and texture change during ripening. In: Recent Advances in the Biochemistry of Fruit and Vegetables, Friend J, Rhodes MJC (Editors), Academic Press, London, UK, p 123-132

43. Nakhasi S, Schlimme D, Solomos T (1991) Storage potential of tomatoes harvested at the breaker stage using modified atmosphere packaging. J Food Sci, 56, 55-59

44. Tomas-Barberan FA, Espin JC (2001) Phenolic compounds and related enzymes as determinants of quality in fruits and vegetables. J Sci Food Agric, 81, 853-876

45. Marsh K, Bugusu B (2007) Food packaging-roles, materials, and environmental issues. J Food Sci, 72, R39-R55 